\title{
Exploring the effects of discarding using the Atlantis ecosystem model for Icelandic waters
}

\author{
Erla Sturludottir \\ Science Institute, University of Iceland, Taeknigardur, Dunhagi 5, 107 Reykjavik, Iceland. \\ E-mail: erlasturl@gmail.com. ORCID iD: http://orcid.org/0000-0002-8829-5469
}

\begin{abstract}
Summary: Discarding fish has been a part of the fisheries for centuries but it has been very difficult to monitor how much is discarded, especially in areas where it is an illegal activity. In this study the ecological and economic effects of discarding were investigated using the Atlantis model for Icelandic waters. Five different scenarios were compared, using different discarding rates and selectivities. The results showed that a complete stop of discarding fish (cod and haddock) and landing everything instead had little ecological and economic impact. Improved selectivity, which would result in not catching the fish that would be discarded, had great beneficial economic effects. The increase in biomass led to higher landings, which consequently led to higher revenue. Also, the cost decreased with increasing biomass, which increased the profit of the fisheries. None of the five scenarios had great ecological effects but only discarding of cod and haddock, which have low discard rates, were considered in this study.
\end{abstract}

Keywords: Icelandic waters; discards; selectivity; ecosystem model; Atlantis; cod; haddock.

Exploración de los efectos de los descartes mediante el modelo ecosistémico Atlantis para aguas islandesas

Resumen: Los descartes han sido parte de la pesca durante siglos, pero es muy difícil evaluar las cantidades descartadas, especialmente en áreas donde constituye una actividad ilegal. En este estudio se investigan los efectos ecológicos y económicos del descarte mediante el uso del modelo Atlantis para aguas islandesas. Se comparan cinco escenarios con distintas tasas de descarte y selectividad. Los resultados muestran que el cese de los descartes de las especies de peces de mayor importancia comercial (bacalao y eglefino) y su descarga en tierra tiene impactos ecológicos y económicos menores. Una mejora de la selectividad que impidiera la captura de la fracción descartada tendría importantes beneficios económicos. El aumento de la biomasa conduciría a una mayor producción comercial y en consecuencia a unos mayores ingresos. Así mismo, los costes disminuirían con niveles de biomasa superiores, amplificando el beneficio económico producido por la pesca. En ninguno de los cinco escenarios se aprecian grandes efectos ecológicos, pero en este estudio solamente se consideran el bacalao y el eglefino, que tienen tasas de descarte relativamente bajas.

Palabras clave: aguas islandesas; descartes; selectividad; modelo ecosistémico; Atlantis; bacalao; eglefino.

Citation/Como citar este artículo: Sturludottir E. 2018. Exploring the effects of discarding using the Atlantis ecosystem model for Icelandic waters. Sci. Mar. 82S1: 51-62. https://doi.org/10.3989/scimar.04736.09A

Editor: F. Maynou.

Received: December 1, 2017. Accepted: March 5, 2018. Published: May 18, 2018.

Copyright: (C) 2018 CSIC. This is an open-access article distributed under the terms of the Creative Commons Attribution 4.0 International (CC BY 4.0) License.

\section{INTRODUCTION}

Discarding has been a part of fisheries for centuries and is still carried out even where there is a discard ban (Alverson et al. 1994, Pálsson 2002). Fishers usually discard fish for economic reasons or to comply with regulations (Kelleher 2005, Eliasen et al. 2014). For example, they discard small target species to 1) increase revenue where larger fish have a higher price, or 2) avoid penalties from minimum landing size re- quirements. They also discard non-target species that 1) have no commercial value or, 2) are not subject to quotas.

The fisheries management system in Iceland aims to reduce discards by enforcing a discard ban but also to make the system flexible to increase compliance by using a transferable quota between species and years (Woods et al. 2015). Also, fish under the minimum size can be landed without counting towards the quota up to a certain limit. The minimum mesh size of bottom 
trawl was also increased during the last century in order to change selectivity (Pálsson 2002), and real-time closures were also implemented to reduce catches and subsequent discarding of small fish (Schopka 2007). However, despite all these mitigations discarding still occurs in Icelandic waters (Pálsson et al. 2012).

It is very difficult to monitor discarding, especially where it is illegal to discard fish (Rochet and Trenkel 2005, Benoît and Allard 2009). It has, however, been attempted to estimate discards in Icelandic waters and the emphasis has been on cod Gadus morhua and haddock Melanogrammus aeglefinus (Pálsson 2002, Pálsson et al. 2012). The method used for Icelandic waters gives estimates of the minimum discard rate, which has been estimated to be $0.2 \%-2.4 \%$ and $1.0 \%-4.8 \%$ of weight from 2001-2010 for cod and haddock, respectively (Pálsson et al. 2012), but the discard rate of haddock was estimated to be $8 \%-22 \%$ late last century (Pálsson 2002).

The practice of discarding is generally viewed as a waste of valuable resources. It is often ignored in stock assessment models, leading to underestimation of fishing mortality, which can have effects on the predictions of the models (Alverson et al. 1994). The ecological impacts of discarding are not well known but discard mortality, just like fishing mortality, can affect predator-prey relationships, which can potentially have a cascading effect through the food web (Alverson et al. 1994). Scavenging species such as some seabirds (e.g. the northern fulmars Fulmarus glacialis in Icelandic waters) have become dependent on discards (Lilliendahl and Sólmundsson 1997). Discarding also has economic impacts (Pascoe 1997). Discarding of commercial species results in less revenue for the fisheries but can be economically beneficial for individual fishers. Discarding species other than the target species can have negative economic effects on other types of fisheries that could otherwise utilize these resources. There is also a cost associated with sorting and discarding by-catch, which should be an incentive for fishers to try to avoid unwanted catch.

Multi-species and ecosystem models can be helpful for exploring the potential ecological and economic impacts of discarding. Hollowed et al. (2000) compared single-species models to multi-species models and concluded that the latter have the advantage of more realistic natural mortality and growth rates, as species interactions are included. Increasing mesh size in single-species and multi-species models can have contradictory results if increased mesh size leads to increased stock size of predators (Pope 1991) resulting in higher predation mortality, which could then actually result in lower total yield with increasing mesh size. This change in predation mortality would, however, be overlooked by single-species models, which would predict higher yield with increased mesh size (Pope 1991). With ecosystem models the effect of the landing obligation and improved selectivity can be explored for the whole ecosystem (Heath et al. 2014). Environmental factors also influence growth and survival of species but are usually excluded from multi-species model (Hollowed et al. 2000).
The end-to-end model Atlantis incorporates both species interactions and environmental factors such as oceanographic conditions and is designed for management strategy evaluation studies (Fulton et al. 2011). The Atlantis modelling framework contains biophysical and fisheries modelling components and management and monitoring components, and it can also incorporate a socio-economic component. Atlantis models can vary in complexity, from relatively simple ecosystem models with few functional groups to models with a complex food web structure and dynamic fisheries models with economic drivers. The groups in the model can have a detailed age-structure and the model tracks the weight and number of each age class. It is therefore an ideal platform for testing alternative management strategies and scenarios and analysing their effects on the whole ecosystem. It has been used to test a number of management scenarios for different areas. It has, for example, been used to test management scenarios with different discarding regulations (Fulton et al. 2007), scenarios of gear shift to reduce by-catch (Kaplan et al. 2012) and different fishing pressure scenarios (Nyamweya et al. 2017).

Selective fisheries should reduce discards (Bellido et al. 2011) and lead to more productive and economically profitable fisheries (Macher et al. 2008, Colloca et al. 2013). Though measures have been taken during the last century to improve selectivity and reduce discards in Icelandic waters, there is still room for further improvements with new fishing gear and fishing practices. The effects on improved selectivity and less discarding for both the fisheries and the whole ecosystem have not been studied for Icelandic waters.

The aim of this study was to investigate the economic and ecological effects of 1) discarding more fish, 2) not discarding, i.e. $100 \%$ compliance with a discard ban, 3) avoiding discarded fish, i.e. more selective fisheries and hence no discards, and 4) knife-edged selectivity at the minimum landing size in the cod and haddock fisheries. The Atlantis model for Icelandic waters was used to explore these scenarios and compare them with a status quo scenario using economic and ecological indicators.

\section{METHODS}

\section{The Atlantis model}

An Atlantis model has been constructed for Icelandic waters and covers $1600000 \mathrm{~km}^{2}$.The ocean area has been divided into 51 spatial boxes and each box is further divided into layers (Fig. 1). The oceanographic model is forced with temperature, salinity and water fluxes that were calculated for each box and layer from a hydrodynamic model (Logemann et al. 2013). The resulting oceanographic data are available as inputs to Atlantis for each day from 1948 to 2012 and the time step of the model is 12 hours.

There are 52 functional groups in the model: 26 vertebrates of which 20 are fish groups, 5 mammals and 1 seabird group, 16 invertebrates, 5 primary producers, 2 bacteria and 3 detritus groups (Table 1). The verte- 


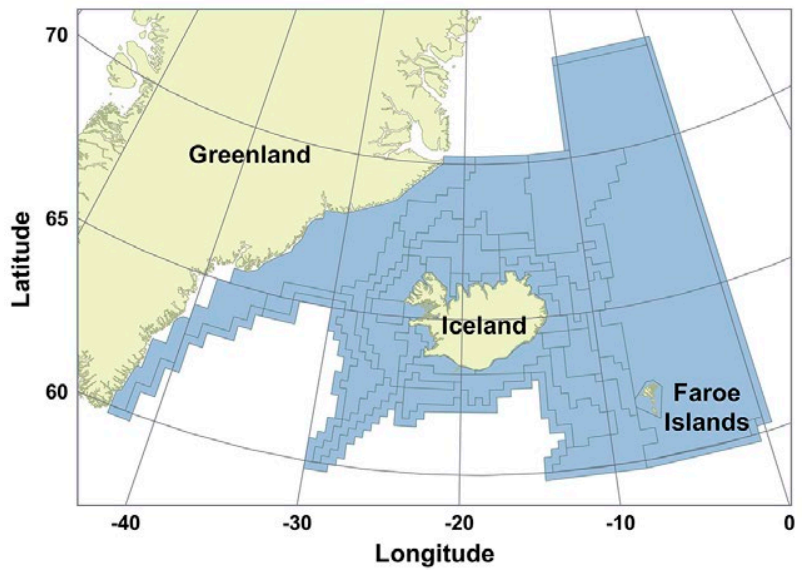

Fig. 1. - The modelled area of the Atlantis model for Icelandic waters and the division of the ocean area into 51 spatial boxes.

brates can have up to ten age classes and their weight is divided into reserve weight, which is soft tissue, and structural weight, which is the bone structure. When the vertebrates die, the reserve weight goes into the labile detritus group, but the structural weight goes into the refractory detritus group. The third detritus group contains the discards that break down into the labile detritus group (Audzijonyte et al. 2017).

The consumption rates of the groups were modelled with the Holling type II function and the availability of each prey was adjusted to make the diet composition of each group resemble diet composition acquired from stomach content data sampled by the Marine and
Table 1. - The code and name of the functional groups in the Atlantis model for Icelandic waters.

\begin{tabular}{llll}
\hline Code & Group & Code & Group \\
\hline FCD & Cod & CEP & Cephalopod \\
FHA & Haddock & PWN & Shrimp \\
FSA & Saithe & ZS & Microzooplankton \\
FRF & Redfish & ZM & Mesozooplankton \\
FGH & Greenland Halibut & ZL & Macrozooplankton \\
FFF & Flatfish & ZG & Gelatinous zooplankton \\
FHE & Herring & LOB & Norway Lobster \\
FCA & Capelin & BML & Megazoobenthos \\
FMI & Blue whiting & SCA & Iceland Scallop \\
FMA & Mackerel & QUA & Ocean Quahog \\
FOC & Other Codfish & CUC & Cucumbers \\
FDC & Demersal Commerical & BD & Deposit Feeder \\
FDF & Other Demersal Fish & BFF & Filter Feeders \\
FSD & Sandeel Fish & BG & Benthic Grazer \\
FDL & Long Lived Demersal & BC & Benthic Carnivore \\
FMP & Large Pelagic Fish & BO & Meiobenthos \\
FBP & Small Pelagic Fish & PL & Diatom \\
SSR & Skates & PS & Pico-phytoplankton \\
SSD & Small Sharks & MA & Macroalgae \\
SSH & Large Sharks & SG & Seagrass \\
SB & Seabird & DF & Dinoflagellates \\
PIN & Pinniped & PB & Pelagic Bacteria \\
WMW & Minke Whale & BB & Sediment Bacteria \\
WHB & Whale Baleen & DL & Labile detritus \\
WHT & Whale Tooth & DR & Refractory detritus \\
WTO & Whale Tooth Other & DC & Discards \\
\hline
\end{tabular}

Freshwater Research Institute (MFRI) or diet composition from the literature (Jónsson and Pálsson 2013, Gunnarsson et al. 1998). The 52 functional groups in the model make up a complex food web (Fig. 2). Recruitment was modelled with the Beverton-Holt function for the fish groups but as a constant per adult for the mammal and seabird groups. Survey data from

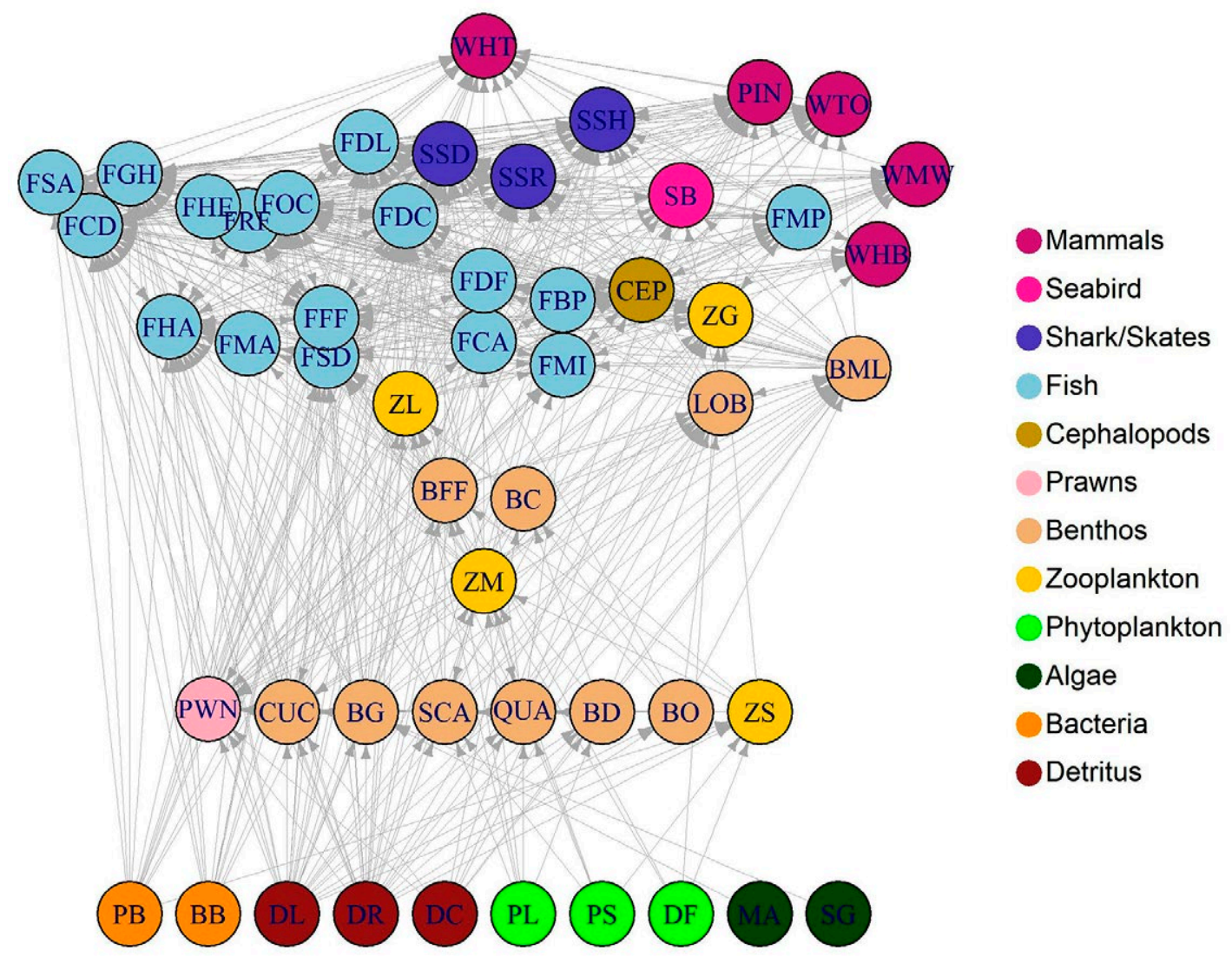

Fig. 2. - The food web of the model. The colours indicate a type of group but see Table 1 for code of individual groups. 
MFRI was used to parameterize the recruitment function and to calculate time-series of recruitment scales for the most important commercial groups (cod, haddock, saithe Pollachius virens, herring Clupea harengus and capelin Mallotus villosus).

Each group has a fixed spatial distribution that can differ from one season to the next. Survey data from the MFRI and information from the literature (Jónsson and Pálsson 2013) were used as a guideline to set the distribution of the groups. The distribution of the plankton groups is controlled by the water fluxes from the oceanographic model.

Fisheries are included in the model as a simple harvest rate for each group that is equal in all areas but is allowed to change between years. The harvest rate is then multiplied with selectivity of each age class to obtain the catch for the harvested groups. The selectivity $\left(p_{i j}\right)$ of each age class $i$ of each group $j$ is modelled by a logistic curve which is based on length:

$$
p_{i j}=\frac{1}{1+\exp \left(-b_{j}\left(l_{i j}-m_{j}\right)\right)}
$$

where $m_{j}$ is the length at 0.5 selectivity, $b_{j}$ controls the steepness of the curve for group $j$, and $l_{i j}$ is the length of age class $i$ of group $j$. There are no interactions between the fisheries, i.e. changed fishing pressure for a group does not have any effect on the fisheries of another group.

The simulated biomass and landings from the model were compared with biomass estimates from the MFRI and landing data (Anon. 2016), and a skill assessment was carried out. The skill of the model was measured with three metrics: Pearson's correlation $(\mathrm{r})$, the model reliability index (RI), and model efficiency (MEF, see Stow et al. 2009 for description of the metrics). The model was able to replicate historical time-series of both biomass and landings for the most important commercial groups. Simulated biomass and landings for cod and haddock had a high correlation with the observed data, and the difference in magnitude of biomass was on average $25 \%$ for cod and $27 \%$ for haddock (Fig. 3). The MEF was positive for both groups, which means that the model gives a better fit than a straight line through the average of the data points.

\section{The discard model}

Only discarding of cod and haddock were assumed in the model and the discard rate was based on estimates from the MFRI (Pálsson 2002, Pálsson et al. 2012). Discarding of other groups occurs in Icelandic waters but has not been researched as much (Pálsson et al. 2003a) and is therefore excluded from the model at this time. The discards of cod and haddock were modelled as proportion discarded of each age class and was based on work done by Pálsson et al. (2012). All catch of the first age class was discarded for both groups, but $20 \%$ and $30 \%$ of the second age class of cod and haddock, respectively were discarded. Some discarding of older fish was also assumed: $5 \%$ of the third age class for both groups and then $<0.5 \%$ for older fish. Studies have shown that large proportions of fish are dead when discarded or die soon afterwards (Alverson 1994,
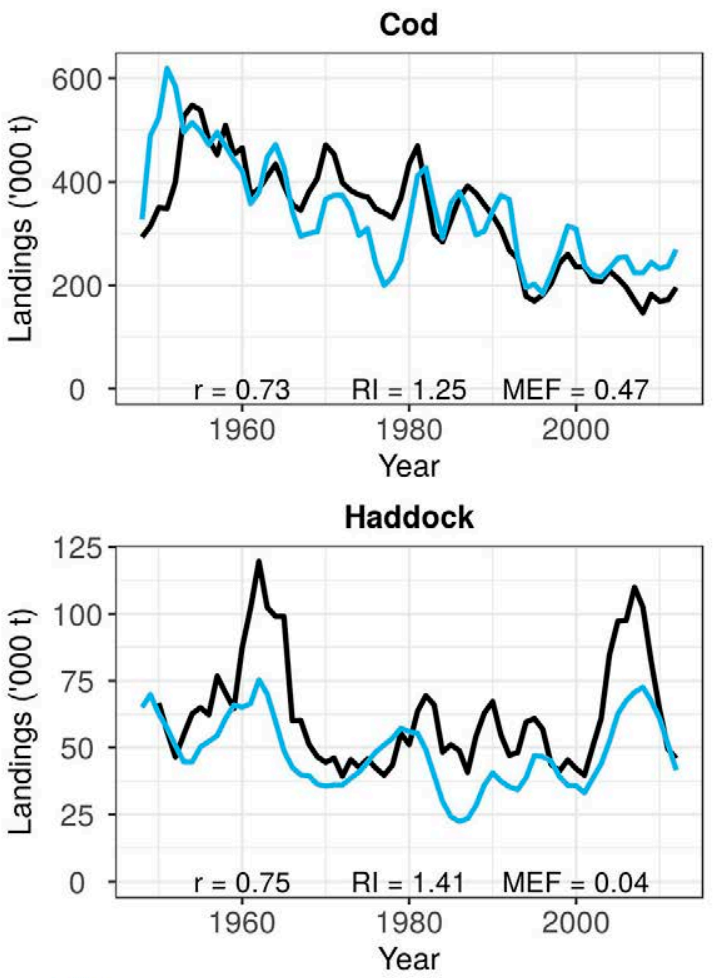

- Simulated biomass/landings

Fig. 3. - Simulated biomass and landings of cod and haddock compared with biomass estimates and landings data using three metrics: Pearson's correlation (r), model reliability (RI) and model efficiency (MEF). 

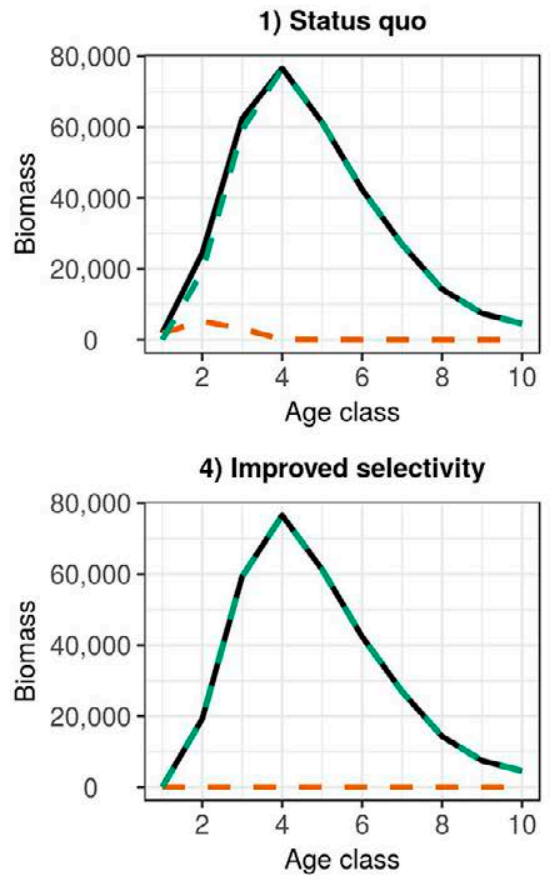

2) More discards

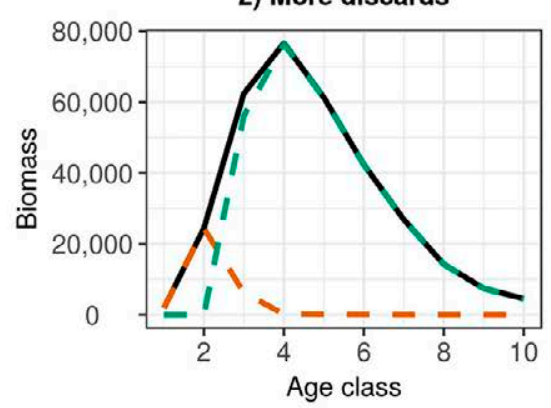

5) Perfect compliance

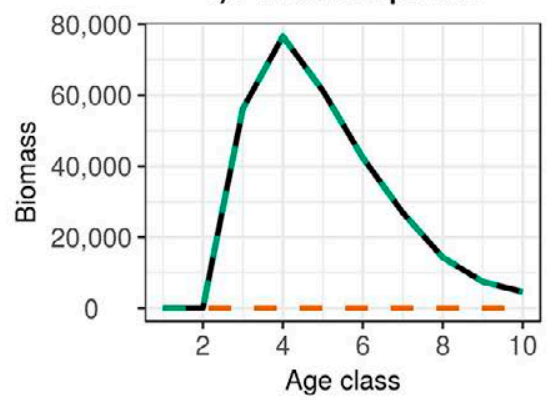

3) No discards

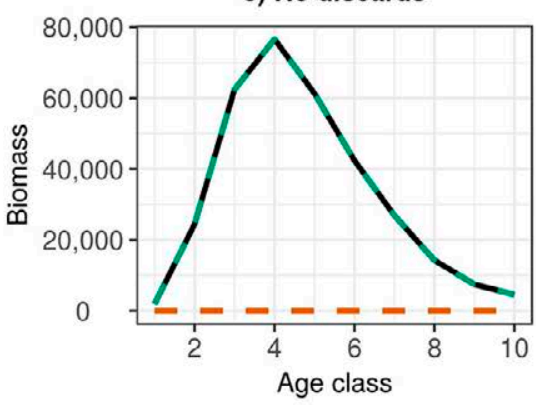

- Catch - Landings - Discards

Fig. 4. - Total biomass of cod and haddock caught, landed and discarded in the first year for each age class for the five scenarios: 1 , Status quo; 2, More discards; 3, No discards; 4, Improved selectivity; and 5, Perfect compliance.

Pálsson et al. 2003b). It was assumed that all discarded fish in the model would die and therefore go into the discard detritus group.

The fate of discards in Icelandic waters is not known, which makes it difficult to determine which groups should feed on the discards. A study has shown that the northern fulmar is dependent on discards in Icelandic waters, where up to $40 \%$ of its diet contains discards, mostly blue whiting Micromesistius poutassou, redfish Sebastes sp. and Norway lobster Nephrops norvegicus (Lilliendahl and Sólmundsson 1997). Discards of these groups were, however, not included in the current model. Therefore, the diet of the seabird group was only assumed to consist of around 5\% of discarded cod and haddock. Cod and haddock were assumed to feed on discards but they were not assumed to be an important component of their diet.

\section{The scenarios}

Five different scenarios were compared (Fig. 4):

1 - Status quo: A discard scenario as described above in the section "The discard model".

2 - More discards: A scenario in which the proportion of each age class for cod and haddock was increased from the status quo scenario. In this scenario all cod and haddock from the first two age classes were discarded and the discard rate was doubled for the other age classes.

3 - No discards: In this scenario no fish were discarded and all caught fish were landed.

4 - Improved selectivity: Reduced selectivity on younger fish and no discarding.

5 - Perfect compliance: knife-edged selectivity at the minimum landing size.

In these five different scenarios, only the discarding parameters were changed. The harvest rate remained the same for the older age classes in all scenarios but was lower for the younger age classes in scenarios where the selectivity was reduced on younger fish (scenarios 4 and 5). Also, parameters that controlled the feeding and diet composition were kept the same in all scenarios. This means that if discarded material is increased then it will also increase in the diet of groups already consuming discards and vice versa.

\section{Ecological and economic indicators}

\section{Demersal fisheries}

An economic indicator, i.e. profit, was calculated for five demersal groups (cod, haddock, saithe, redfish and Greenland halibut Reinhardtius hippoglossoides). This indicator of profit is for the society but not for the individual fisher, so the cost of labour is not taken into account.

The price of fish was taken as the average for 2012, acquired from the Fresh-Fish Price Directorate (http:// verdlagsstofa.is/). The price of fish depends on the weight of the demersal fish except for Greenland halibut. The prices of cod and haddock are given for every $100 \mathrm{~g}$ and for every $50 \mathrm{~g}$ for redfish. The price of saithe is only different for four weight categories and a fixed price is given if the fish are under the minimal legal size (Fig. 5). If a fish from the model weighed more than the maximum weight in the price tables, the price was set as the maximum price.

The modelled cost was adapted from Björnsson and Hjörleifsson (2015). The cost per ton of yield was considered, because the fisheries model is not based on effort. The cost of oil, gear, maintenance and depreciation was 44800 ISK per ton of caught fish in the year 

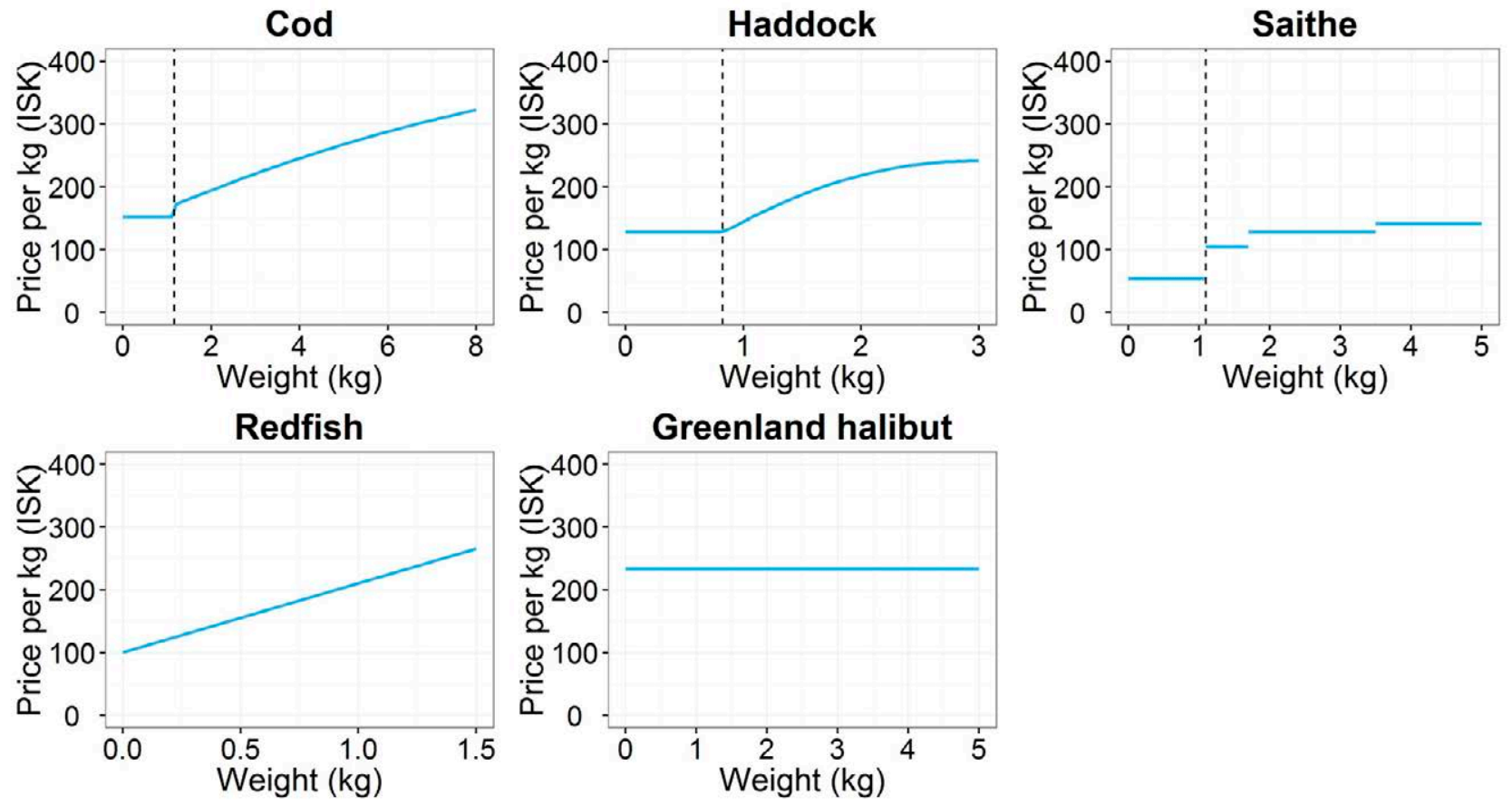

Fig. 5. - The price per kg of cod, haddock, saithe, redfish and Greenland halibut. The dotted line shows the minimum legal size.

2012 for trawlers (freezer trawlers excluded, Statistics Iceland 2016) and this was set as the cost in the status quo scenario. It was assumed that the cost had an inverse relationship with biomass. Equation 2 describes the $\operatorname{cost}\left(C_{\mathrm{s}, \mathrm{i}, \mathrm{t}}\right)$ associated with fishing demersal species $s$ in scenario $i$ at time $t$ :

$$
C_{s, i, t}=44,800 *\left(\frac{B_{s, 1,2012}}{B_{s, i, t}}\right)^{\gamma}
$$

where $B_{s, i, t}$ is the biomass of demersal species $s$ in scenario $i$ at time $t$ and $\gamma=0.8$. The value of $\gamma$ is based on the relationship between catch per unit effort (CPUE) and stock size of cod (Anon. 2004), which is then assumed to be the same for the other demersal species. The proportional change of CPUE ( $\triangle \mathrm{CPUE}$ ) from time $t$ to time $t+k$ can be described as

$$
\triangle C P U E=\left(\frac{B_{t+k}}{B_{t}}\right)^{0.8}
$$

where $B_{t}$ is the stock size at time $t$. Hence, if the biomass doubles, the CPUE will increase by $74 \%$ and the cost per ton harvested will subsequently decrease by $43 \%$.

The profit for each species $s$ in each scenario $i$ at time $t$ was calculated as

$$
\text { Profit }_{s, i, t}=\sum_{w}\left(Y_{w, s, i, t} * p_{w, s}\right)-C_{s, i, t} \sum_{w}\left(Y_{w, s, i, t}+D_{w, s, i, t}\right)
$$

where $Y_{w, s i, t}$ and $D_{w, s, i, t}$ are the total landings and discards of a certain weight group $w$ of species $s$ in scenario $i$ at time $t$ and $p_{w, s}$ is the price for that group. The profit was presented for cod and haddock individually but aggregated for saithe, redfish and Greenland halibut.

\section{Pelagic fisheries}

The most important pelagic species with commercial value are herring, capelin, blue whiting and the mackerel Scomber scombrus. These species have a schooling behaviour and costs associated with these fisheries have different characteristics from those of the demersal fisheries (Sandberg 2006). The demersal fisheries use $63 \%$ of their fuel consumption when trawling, but the herring fisheries use only $5 \%$ of the total fuel for actual fishing (Björnson 2004). Therefore, a different method for calculating economic indicators was used for the pelagic groups.

The stock size should not affect the cost of fishing in pelagic fisheries unless more time is spent searching for the schools when the stock size is low. In some herring fisheries in Norway the stock size did not have a significant effect on the cost of fishing (Sandberg 2006). It will therefore be assumed that the cost is constant per ton of harvested pelagic fish. This constant cost is however assumed to be different between the fisheries. It has been estimated that the fuel use associated with the fisheries is 20,82 and $90 \mathrm{~L}$ per ton for capelin, herring and blue whiting, respectively (Björnsson 2004). There is no estimate for mackerel but it will be assumed that the cost is the same as for the herring because it is harvested closer to land than the blue whiting.

In 2012 the fuel cost per pelagic trawler (freezertrawler excluded) in Iceland was 3839 million ISK (Statistics Iceland 2016). That same year 126, 456, 40 and 67 thousand tonnes were harvested by these trawlers of herring, capelin, blue whiting and mackerel, respectively. The cost of fuel can then be divided between the different fisheries assuming the different fuel use and fuel cost per ton harvested (Table 2). Total cost 
Table 2. - Price per kg and cost per ton of pelagic fisheries in 2012.

\begin{tabular}{lccccc}
\hline Species & Price (ISK/kg) & Fuel cost per ton (ISK) & $\begin{array}{c}\text { Fishing gear cost } \\
\text { per ton (ISK) }\end{array}$ & $\begin{array}{c}\text { Maintenance cost } \\
\text { per ton (ISK) }\end{array}$ & Total cost per ton (ISK) \\
\hline Herring & 49 & 11,010 & 1,647 & 2,156 & 14,813 \\
Capelin & 25 & 2,685 & 1,647 & 2,156 & 6,488 \\
Blue whiting & 26 & 12,084 & 1,647 & 2,156 & 15,887 \\
Mackerel & 52 & 11,010 & 1,647 & 2,156 & 14,813 \\
\hline
\end{tabular}

of fishing gear was 1135 million ISK and total cost of maintenance was 1487 million ISK in 2012 (Statistics Iceland 2016). The cost of gear and maintenance was assumed to be the same for the four fisheries and the cost per ton can be seen in Table 2 . The profit $\left(P_{s, i, t}\right)$ for pelagic species $s$ in scenario $i$ at time $t$ then becomes

$$
P_{s, i, t}=p_{s} * Y_{s, i, t}-C_{s} *\left(Y_{s, i, t}+D_{s, i, t}\right)
$$

where $Y_{s, i, t}$ and $D_{s, i, t}$ are the total landings and discards of species $s$ in scenario $i$ at time $t, p_{s}$ is the price per ton for that species and $C_{s}$ is the total cost per ton harvested. The profit was then aggregated over all pelagic species and over all demersal and pelagic species. Note that in this study the focus is on the relative change in profit between scenarios but not on absolute values and that a fixed cost is excluded from the cost functions for the demersal and pelagic fisheries.

\section{RESULTS}

\section{Effects on commercial groups}

The simulated discard rate for the status quo scenario was on average $1 \%$ and $7 \%$ by weight and $11 \%$ and $23 \%$ by numbers for cod and haddock, respec-

1) Status quo
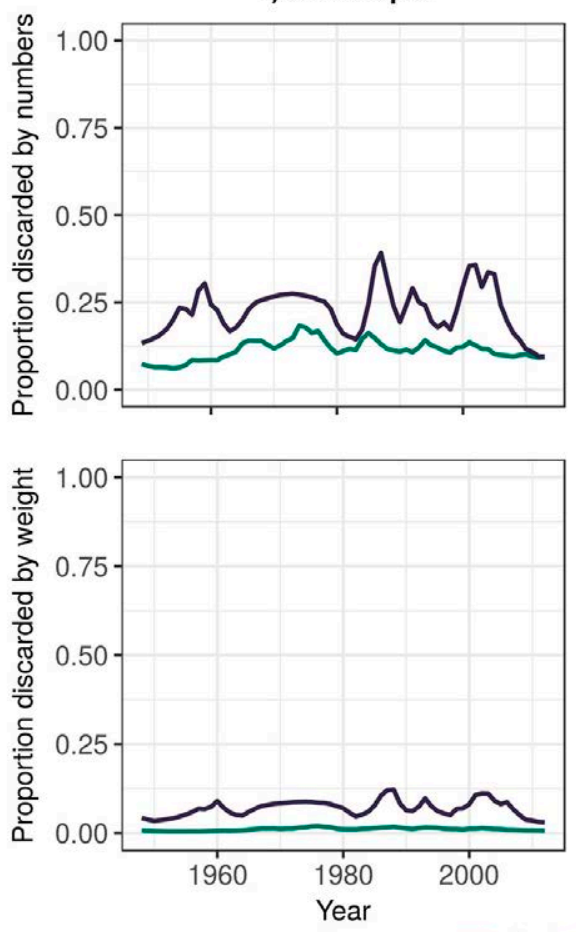

- Cod - Haddock tively (Fig. 6). This corresponds to an average of 9.3 million individual cod and 11.5 million haddock being discarded annually. In scenario 2, in which more fish were discarded, the average discard rate went up to $3 \%$ and $18 \%$ for cod and haddock by weight and to $23 \%$ and $43 \%$ by numbers, which corresponds to 19.4 and 21.9 million discarded cod and haddock individuals, respectively. There were no discarded fish in the other scenarios.

The results from scenarios 2-5 were compared with the results from scenario 1 , the status quo scenario. Increasing or reducing the discard rate (scenarios 2 and 3 ) had very little effect on the biomass of cod and haddock and resulted in a change of $<0.5 \%$ from the status quo scenario (Fig. 7). On the other hand, improving the selectivity and avoiding discarded fish and juveniles (scenarios 4 and 5) had positive effects on the biomass, with an average increase in cod biomass from the status quo scenario of $4 \%$ and $9 \%$ for scenarios 4 and 5, respectively. The average increase was higher for the haddock: $13 \%$ for scenario 4 and $28 \%$ for scenario 5 . The difference was, however, more appreciable later in the period than at the beginning. For example, the increase in biomass for cod in the first 10 years was $2 \%$ in scenario 5 but $13 \%$ in the last ten years of the simulation (Fig. 7). The biomass of the other demersal spe-
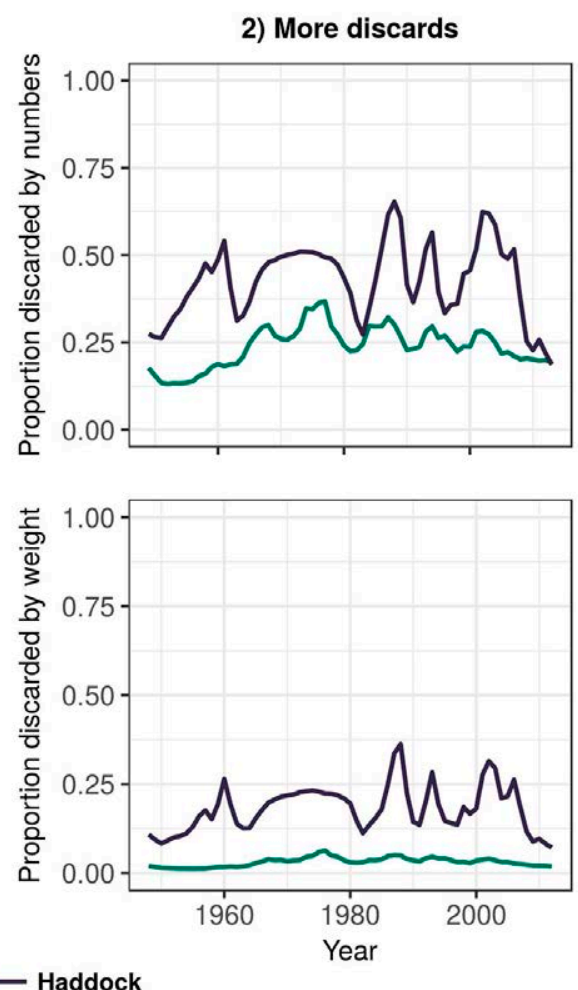

Fig. 6. - Simulated discard rate of cod and haddock by numbers and weight for scenario 1 and 2 (no discards in other scenarios). 

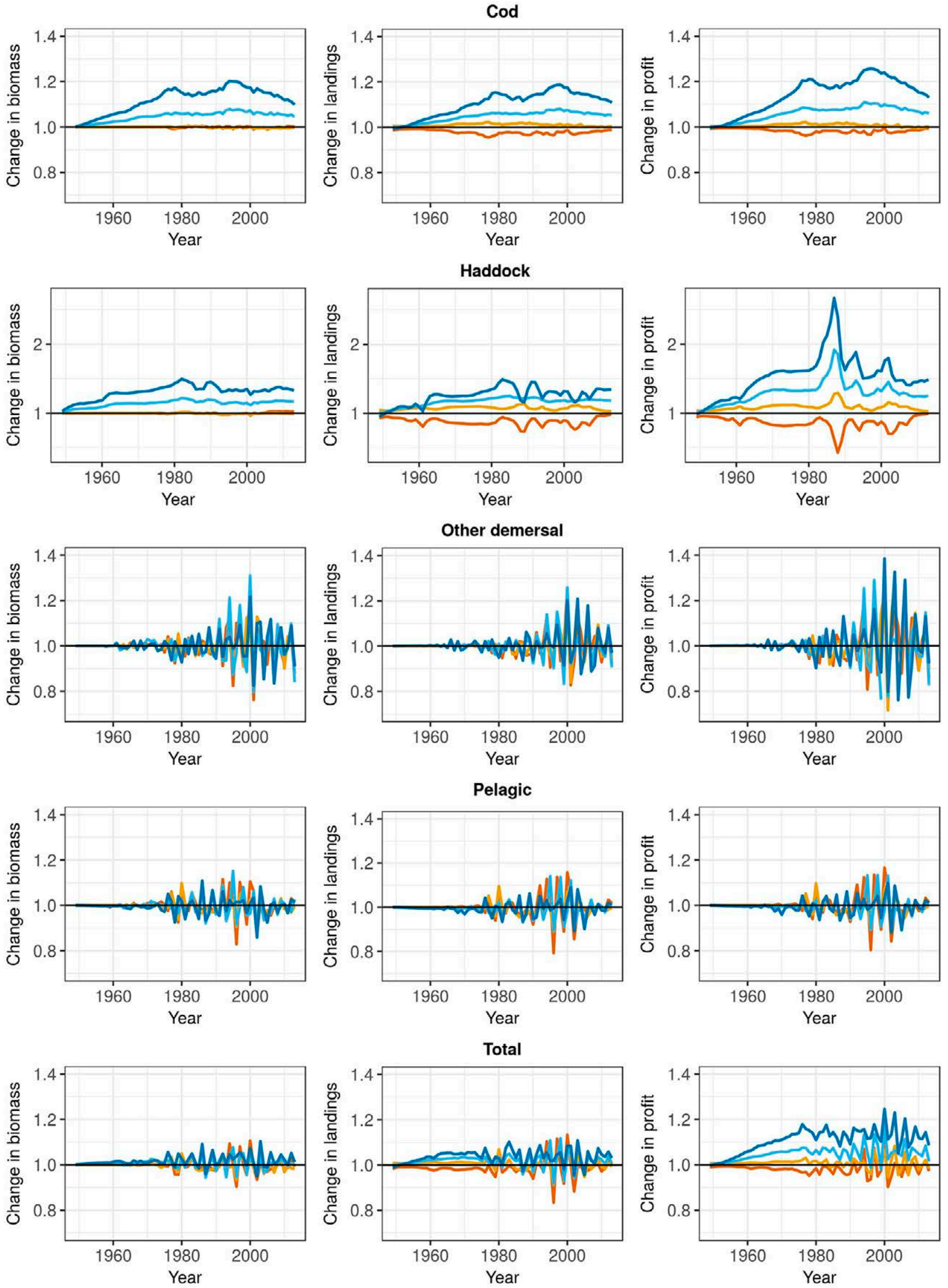

- 1) Status quo - 2) More discards - 3) No discards - 4) Improved selectivity - 5) Perfect compliance

Fig. 7. - Relative change in simulated biomass, landings and profit for cod, haddock, demersal species (saithe, redfish, Greenland halibut) and pelagic species (capelin, herring, blue whiting and mackerel) for the five scenarios compared the status quo scenario. 
cies (saithe, redfish and Greenland halibut) and pelagic species (capelin, herring, blue whiting and mackerel) was very similar on average in all scenarios (Fig. 7). The largest difference in other demersal biomass was $1 \%$ on average between the status quo scenario and scenario 4 for the last 20 years of the simulation. The pelagic biomass was $1 \%$ lower on average for the last 20 years of the simulation in scenario 5 than in the status quo scenario. When biomass of all commercial species is considered, the average difference was $<0.5 \%$, except in scenario 5, where it was $2 \%$ higher than in the status quo scenario.

Increasing the discard rate resulted in decreased landings of cod and haddock, as expected (Fig. 7). The average decrease was, however, only $2 \%$ for cod but $12 \%$ for haddock. Scenario 3 where no fish were discarded had $0.8 \%$ and $7 \%$ more landings for cod and haddock on average than the status quo scenario. The improved selectivity of scenario 4 and 5 resulted in higher biomass and consequently also in higher landings compared with the status quo scenario. The cod landings were $4 \%$ and $9 \%$ higher in scenarios 4 and 5 and haddock landings were $16 \%$ higher in scenario 4 and $25 \%$ higher in scenario 5 . The effects of improved selectivity on landings were delayed, i.e. the difference between the two scenarios and the status quo scenario was larger towards the end of the simulation than at the beginning. The average difference in demersal and pelagic landings was negligible between scenarios and the difference in landings of all commercial species was largest for scenario 5, in which the average landings were $3 \%$ higher than in the status quo scenario.

The profit from the cod fisheries decreased by $1 \%$ over the whole simulated period when the discard rate was increased (scenario 2), but it increased by $0.7 \%$ when all fish were landed (scenario 3). Scenarios 4 and 5 gave $5 \%$ and $11 \%$ more profit, respectively, than the status quo scenario for cod. The difference between scenarios was greater for haddock, with scenarios 4 and 5 giving respectively $24 \%$ and $43 \%$ more profit

Seabird

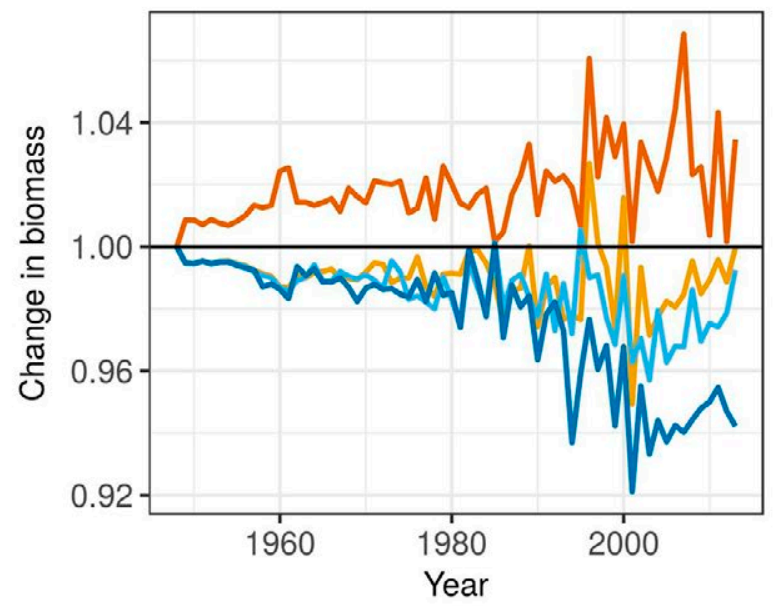

over the whole period than the status quo scenario. Bringing all fish to land gave $7 \%$ more profit than the status quo scenario but the scenario in which more fish were discarded gave $11 \%$ less profit for haddock. There was no difference in profit for the demersal species for the first 30 years of the simulation, but in the last 10 years there was a slight difference on average between the scenarios $(<1 \%)$. The average profit in the pelagic fisheries was very similar in all scenarios (Fig. 7). The average change in profit when all the fisheries were considered was very similar to the changes in the cod fisheries. The average profit was $5 \%$ and $10 \%$ higher in scenarios 4 and 5, respectively, than in the status quo scenario. Scenario 3 gave $1 \%$ more profit and scenario 2 gave $2 \%$ less profit than the status quo scenario.

\section{Ecological effects}

The increased biomass of cod and haddock when selectivity was improved (scenarios 4 and 5) did not have much effect on other vertebrate groups in the system. Most fish groups decreased slightly in biomass when the biomass of cod and haddock increased, though the pelagic groups showed different fluctuations in biomass. The top predators (pinnipeds, tooth whale and sharks) that had cod and haddock in their diet increased in biomass. The largest effects were observed to be on flatfish, sandeel and pinnipeds. In comparison with the status quo scenario, the flatfish had 3\% and $7 \%$ lower biomass in scenarios 4 and 5, respectively, and the pinniped group had $1 \%$ and $3 \%$ higher biomass, respectively. The biomass of sandeel also benefitted from improved selectivity of cod and haddock, and in the last ten years the biomass was $9 \%$ higher than in the status quo scenario. Seabirds are the group in the model that feeds the most on discards. It had $4 \%$ higher biomass in scenario 2 , in which the discard rate was increased, than in scenario 3 , in which there were no discards. The seabird biomass was lowest in scenario 5 , with a value $5 \%$ lower than in the status quo scenario in the last ten years of the simulation (Fig. 8).

Sandeel

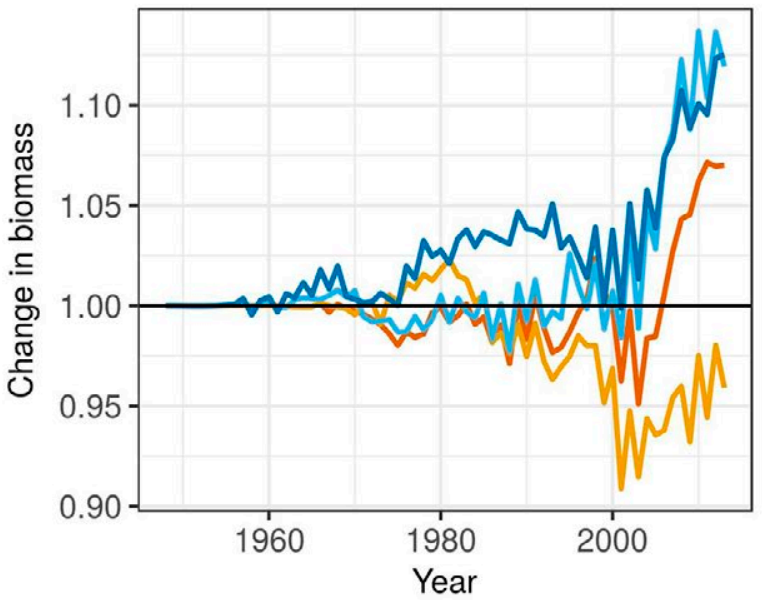

- 1) Status quo - 2) More discards - 3) No discards - 4) Improved selectivity - 5) Perfect compliance

Fig. 8. - Relative change in simulated biomass of seabird and sandeel for the five scenarios compared the status quo scenario. 


\section{DISCUSSION}

\section{The discard rate}

The simulated discard rate of haddock in the status quo scenario ranged from $3 \%$ to $12 \%$ by weight and from $9 \%$ to $39 \%$ by numbers over the 65 -year period. These values are comparable to available estimates from 1988 to 2000 , which ranged from $8 \%$ to $22 \%$ by weight and from $12 \%$ to $50 \%$ by numbers (Pálsson 2002). The average number of discarded haddock in the status quo scenario was 11.5 million fish or 3460 $\mathrm{t}$, which is close to the estimate of 8.4 million fish corresponding to 4852 tonnes (Pálsson 2002). Active monitoring of discards began in 2001 and the discard rate has been estimated to be lower after the turn of the century, when it ranged from $1 \%$ to $5 \%$ by weight and from $3 \%$ to $10 \%$ by numbers (Pálsson et al. 2012). Estimates of discard rate of cod are only available from 2001 and range from $0.2 \%$ to $2.4 \%$ by weight and $0.5 \%$ to $5.6 \%$ by numbers. The discard rate of cod simulated by the model ranged from $0.4 \%$ to $2 \%$ by weight and from $6 \%$ to $19 \%$ by numbers. The model projects more discarding of younger and smaller fish than was estimated, but it is likely that the discard rate of cod was higher before 2000, in accordance with the discard rate of haddock. The discard rate for cod and haddock in the status quo scenario could therefore be similar to what it was in Icelandic waters, at least before 2000. The discard rate in Icelandic waters is considered to be low: by comparison the discard rate by numbers in the North Sea has been estimated to be $20 \%$ to $48 \%$ for cod and $30 \%$ to $41 \%$ for haddock (Cotter et al. 2002). However, the method used to estimate discards in Icelandic waters gives a lower bound on the discard rate as it is based on length composition but does not consider fish discarded in other fisheries such as shrimp fisheries.

The discard behaviour cannot be modelled with the present fisheries model. For example, the discard rate of small and medium-sized fish has been observed to be higher when the stock is low (Pálsson 2002), but the model cannot track this behaviour. Despite this flaw, the study should give insight into the effects of fishing and discarding unwanted catch.

\section{Effects of discarding on commercial species}

Discarding more fish or landing all fish as in scenarios 2 and 3 had little effect on the biomass of the commercial species, as the fishing mortality was the same as in the status quo scenario. It also had little effect on the landings and profit, as the biomass of the discarded fish is low, even though their numbers are high. Another study on the effect of discards in the North Sea showed that landing discards had no effect on the stock size of fish groups (Heath et al. 2014).

In scenario 3, it was assumed that there was $100 \%$ compliance with a discard ban. In countries where the discard ban has been enforced discarding still exists (Condie et al. 2014). Bringing all caught fish to land is something fishermen could do as long as they have enough space onboard their vessel. In this scenario it, was assumed that a total allowable catch (TAC) did not constrain the catch. This is not realistic for Icelandic waters and hence the landings and profit are higher than they should be if a TAC were in place. Fulton et al. (2007) tested different management scenarios with an Atlantis model which included a dynamic fisheries model. Their study showed that compliance with the discard ban may result in a change in fishermen's behaviour and a change of fishing grounds. The current study did not have a dynamic fisheries model, so this aspect could not be studied.

\section{Effects of improved selectivity on commercial species}

The increase in landings in scenarios 4 and 5 compared with the status quo scenario was almost as high as the increase in biomass, though the juveniles were targeted less or not at all whereas they accounted for around $10 \%$ of the total landings of haddock in the status quo scenario. The positive effects of not fishing juveniles were delayed. It took four years for the first cohort to reach the fishable stock and 20 years to reach the oldest age. Not fishing juveniles also meant larger spawning stock biomass, which led to increased number of recruits, but the increase did not peak until after more than 20 years, when the recruitment was $4.6 \%$ and $9.1 \%$ higher for cod and haddock, respectively.

The profit from the fisheries was much higher in scenarios 4 and 5 than the landings indicated. The increased biomass resulted in less cost per harvested ton. The cost per ton was 5\% lower in scenario 5 than in the status quo scenario for all fisheries combined but was as much as $31 \%$ less in the haddock fisheries. The higher the cost per ton in Equation 2, the larger the relative change in profit will be with increasing biomass. Therefore, if the cost of fishing were assumed to be higher, the relative change of profit from scenarios 4 and 5 would become greater. Note that the cost of fishing was assumed to be the same for all demersal species, but this is probably not the case, because haddock is fished closer to land than cod and redfish. Not only did the cost decrease but the average fish price increased because older and larger fish were being caught. The average price per $\mathrm{kg}$ of haddock was $3 \%$ higher in scenario 5 than in the status quo scenario. The combined effects of increased landings, decreased cost and increased price resulted in a $5 \%$ and $10 \%$ higher profit for all fisheries in scenarios 4 and 5 than in the status quo scenario. The modelled cost of fishing when juveniles are avoided may be underestimated, because the swept area would be the same unless avoiding juveniles is a result of different fishing grounds. There is also a cost associated with discards which is difficult to estimate: fish that are discarded need to be removed from the fishing gear and sorted (Pascoe 1997). This cost is mostly in the form of labour, which was not considered in this study.

The increased biomass, landings and profit from the commercial species in the improved selectivity scenarios are consistent with results from other modelling studies (Macher et al. 2008, Colloca et al. 2013). The 
study by Macher et al. (2008) on Nephrops fisheries showed that higher selectivity towards larger individuals resulted in higher biomass but led to decreased landings when only large individuals were fished, without a reduction in revenue.

Two of the scenarios explore the effects of improved selectivity, one in which discarded fish from the status quo scenario are not caught and another in which juveniles are completely avoided. Not fishing any juveniles is a very difficult, if not impossible, task; it makes scenario 5 a utopian scenario but clearly an ideal one as it gave much more profit than the other ones. There have been improvements in selectivity in Icelandic fisheries in the last century when the mesh size was increased and a real-time closure system was implemented (Pálsson 2002, Schopka 2007). Further improvements are possible as new fishing gear and technology along with new fishing practices are being developed and tested. Ongoing projects have been set up with this aim, such as the MINOUW project (http://minouw-project.eu/) and Discardless (http://www.discardless.eu/). A previous project in which fishers designed their own fishing gear led to improved selectivity, and discards were reduced by 52\% (Armstrong and Revill 2010). There are a number of other measures, in addition to more selective gear, that can be implemented to improve selectivity and reduce discards, such as having an observer or remote electronic monitoring (REM) system onboard vessels. Fishermen behaviour has been observed to change when REM equipment was installed onboard their vessels, leading to more selective fishing (Course et al. 2011). The attitude of fisherman is also believed to be an important factor in selective fishing and discards (Valdemarsen 2003). Increasing their awareness to change their attitude and fishing behaviour is therefore an important component to consider in improving selectivity.

\section{Ecological effects}

Seabirds were the group in the model that fed the most on discarded fish. The discards made up around $5 \%$ of their diet in the status quo scenario and $10 \%$ in the scenario with more discards. They fed mainly on sandeel but when the sandeel population collapsed, large zooplankton, capelin, herring, shrimp, megazoobenthos and discards become more important. The seabird biomass was lowest in the scenarios in which there were no discards and highest in the scenario in which the discard rate was increased. The increased discards were, however, not sufficient to compensate for the collapse of the sandeel population, and the seabird group also collapsed in that case.

The changes in biomass of the commercial groups in the scenarios had a slight impact on other groups in the model. The reason for the changes were threefold: 1) the increased biomass in scenarios 4 and 5 caused more feed for the top predators, which increased their biomass; 2) the increased biomass of cod and haddock resulted in increased predation mortality of their prey species, leading to decreased biomass of those groups; and 3 ) the changes in the commercial groups had an indirect effect on another group, leading to changes in the lower trophic levels (e.g. zooplankton), which cascaded through the food web, causing several fluctuations in biomass of some of the groups, especially the pelagic fish groups.

Sandeel was a group that was affected, especially towards the end of the simulation. It is not obvious what causes the changes in the sandeel biomass, but a sensitivity study that was conducted on this model showed that sandeel was most sensitive towards changes in saithe, redfish, flatfish, blue whiting and seabird groups. Most of the changes are probably attributed to changes in the seabird group, which is its main predator, but also to changes in the flatfish group, which competes for the same prey as the sandeel.

Another study on the effect of landing discards and improving selectivity in the North Sea using an ecosystem model showed that landing discards had negative impacts on seabirds and mammals (Heath et al. 2014), a finding which is consistent with those of the present study. Heat et al. (2014) did, however, observe that seabirds and mammals could benefit from improved selectivity (depending on fishing pressure), which was not the case for the seabirds in the present study, though some of the mammals (e.g. pinnipeds) showed increasing biomass. There were only minor ecological effects of discards in this study, but it should be noted that only discards of cod and haddock, which have low discard rates, were considered. Considerable amounts of discarded redfish and blue whiting are likely to occur in practice, as earlier studies have shown that the diet of seabirds can consist of up to $40 \%$ of discards, which are mainly from these two groups (Lilliendahl and Sólmundsson 1997). Non-commercial discards and over-quota discards of other commercial species are also not included in the study, but there are no estimates of these types of discards for Icelandic waters. Stronger ecological effects are expected if all possible discards of all groups are considered.

\section{CONCLUSION}

The Atlantis modelling framework can be used to test different discarding and selectivity scenarios and to evaluate the impact on the harvested groups and on non-commercial groups in the system. This study showed that landing all discarded fish has little affect when the discard rate is low. Improving selectivity and avoiding the fish (juveniles) that would usually be discarded has great positive benefits. The biomass and landings increase and the profit from the landings is amplified because the cost per ton decreases with increasing biomass and the price of the fish also increases because larger fish are caught. It can therefore be concluded that selectivity is an important factor that should be improved by developing new fishing gear and adopting new fishing practices.

\section{ACKNOWLEDGEMENTS}

This study received funding from the European Commission's Horizon 2020 Research and Innova- 
tion Programme under Grant Agreement No. 634495 for the Science, Technology, and Society Initiative to Minimize Unwanted Catches in European Fisheries (MINOUW). I would also like to thank Gunnar Stefansson at the University of Iceland for helpful discussions on this topic.

\section{REFERENCES}

Alverson D.L., Freeberg M.H., Murawski S.A., et al. 1994. A global assessment of fisheries bycatch and discards. FAO Fisheries Technical Paper No. 339. FAO, Rome, Italy, 233 pp.

Anon. 2004. Aflaregla fyrir porskveiðar á Íslandsmiðum: skýrsla nefndar um langtímanýtingu fiskistofna. Skýrsla til sjávarútvegráðherra (e. report for the Ministry of Fisheries) (in Icelandic).

Anon. 2016. State of Marine Stocks in Icelandic Waters 2015/2016 and Prospects for the Quota Year 2016/2017. Marine Research in Iceland 185. The Marine Research Institution, Reykjavik, Iceland.

Armstrong S., Revill A. 2010. Devon beam trawlermen reduce discarded juvenile fish by over $50 \%$. Cefas, Lowestoft, UK

Audzijonyte A., Gorton R., Kaplan I., et al. 2017. Atlantis User's guide Part I: General overview, physics \& ecology. CSIRO, Hobart, Australia, 206 pp.

Bellido J.M., Santos M.B., Pennino M.G., et al. 2011. Fishery discards and bycatch: solutions for an ecosystem approach to fisheries management? Hydrobiologia 670: 317-333 https://doi.org/10.1007/s10750-011-0721-5

Benoît H.P., Allard J. 2009. Can the data from at-sea observer surveys be used to make general inferences about catch composition and discards? Can. J. Fish. Aquat. Sci. 66: 2025-2039. https://doi.org/10.1139/F09-116

Björnsson E. 2004. Olíunotkun íslenskra fiskiskipaflotans (e. Oil consumption of the Icelandic fishing fleet). University of Akureyri, Iceland (in Icelandic).

Björnsson H., Hjörleifsson E. 2015. Athugun á aflareglu fyrir íslenskan porsk (e. Harvest control rule for Icelandic cod). Marine Research Institution, Reykjavik, Iceland (in Icelandic).

Colloca F., Cardinale M., Maynou F., et al. 2013. Rebuilding Mediterranean fisheries: a new paradigm for ecological sustainability. Fish Fish. 14: 89-109 https://doi.org/10.1111/j.1467-2979.2011.00453.x

Condie H.M., Grant A., Catchpole T.L. 2014. Incentivising selective fishing under a policy to ban discards; lessons from European and global fisheries. Mar. Policy 45: 287-292. https://doi.org/10.1016/j.marpol.2013.09.001

Cotter A.J.R., Course G., Buckland S.T., et al. 2002. A PPS sample survey of English fishing vessels to estimate discarding and retention of North Sea cod, haddock, and whiting. Fish. Res. 55: 25-35. https://doi.org/10.1016/S0165-7836(01)00306-X

Course G., Pasco G., Revill A., et al. 2011. The English North Sea Catch-Quota pilot scheme - Using REM as a verification tool. Cefas, Lowestoft, UK.

Eliasen S.Q., Papadopoulou K.N., Vassilopoulou V., et al. 2014. Socio-economic and institutional incentives influencing fishers' behaviour in relation to fishing practices and discard. ICES J. Mar. Sci. 71: 1298-1307. https://doi.org/10.1093/icesims/fst120

Fulton E.A., Smith A.D.M., Smith D.C. 2007. Alternative management strategies for southeast Australian commonwealth fisheries: stage 2: quantitative management strategy evaluation. CSIRO, Hobart, Australia.

Fulton E.A., Link J.S., Kaplan I.C., et al. 2011. Lessons in modelling and management of marine ecosystems: the Atlantis experience. Fish Fish. 12: 171-188. https://doi.org/10.1111/j.1467-2979.2011.00412.x

Gunnarsson K., Jónsson G., Pálsson Ó.K. 1998. Sjávarnytjar við Ísland (e. marine resources around Iceland). Mál og Menning, Reykjavik, Iceland, $282 \mathrm{pp}$ (in Icelandic).

Heath M.R., Cook R.M., Cameron A.I., et al. 2014. Cascading ecological effects of eliminating fishery discards. Nat. Commun. 5: 3893 . https://doi.org/10.1038/ncomms4893

Hollowed A.B., Bax N., Beamish R., et al. 2000. Are multispecies models an improvement on single-species models for measuring fishing impacts on marine ecosystems? ICES J. Mar. Sci. 57: 707-719.

https://doi.org/10.1006/jmsc.2000.0734

Jónsson G, Pálsson J. 2013. Íslenski fiskar (e. Icelandic fish). Mál og Menning, Reykjavik, Iceland, 493 pp (in Icelandic).

Kaplan I.C., Horne P.J., Levin P.S. 2012. Screening California Current fishery management scenarios using the Atlantis end-toend ecosystem model. Prog. Oceanogr. 102: 5-18. https://doi.org/10.1016/j.pocean.2012.03.009

Kelleher K. 2005. Discards in the World's Marine Fisheries: An Update. FAO Fisheries Technical Paper No. 470. FAO, Rome, Italy, $131 \mathrm{pp}$

Lilliendahl K., Sólmundsson J. 1997. An estimate of summer food consumption of six seabird species in Iceland. ICES J. Mar. Sci. 54: 624-630. https://doi.org/10.1006/jmsc. 1997.0240

Logemann K., Ólafsson J., Snorrason Á., et al. 2013. The circulation of Icelandic waters - a modelling study. Ocean Sci. 9: 931-955. https://doi.org/10.5194/os-9-931-2013

Macher C., Guyader O., Talidec C., et al. 2008. A cost-benefit analysis of improving trawl selectivity in the case of discards: the Nephrops norvegicus fishery in the Bay of Biscay. Fish. Res. 92: 76-89. https://doi.org/10.1016/j.fishres.2007.12.021

Nyamweya C.S., Sturludottir E., Tomasson T., et al. 2017. Prediction of Lake Victoria's response to varied fishing regimes using the Atlantis ecosystem model. Fish. Res. 194: 76-83. https://doi.org/10.1016/j.fishres.2017.05.014

Pálsson Ó.K. 2002. Brottkast ýsu á Íslandsmiðum (e. discards of haddock in Icelandic waters). Ægir 95: 32-37 (in Icelandic).

Pálsson Ó.K., Karlsson G., Arason A., et al. 2003a. Mælingar á brottkasti botnfiska 2002 (e. Discards in demersal Icelandic fisheries 2002). Report series nr. 94. The Marine Research Institution, Reykjavik, Iceland (in Icelandic with English summary).

Pálsson Ó.K., Einarsson H.A., Björnsson H. 2003b. Survival experiments of undersized cod in a hand-line fishery at Iceland. Fish. Res. 61: 73-86. https://doi.org/10.1016/S0165-7836(02)00248-5

Pálsson Ó.K., Björnsson H., Gísladóttir H., et al. 2012. Mælingar á brottkasti porsks og ýsu 2001-2010 (e. estimations of discards of cod and haddock 2001-2010). Hafrannsóknir nr. 160. The Marine Research Institution, Reykjavik, Iceland (in Icelandic with English summary).

Pascoe S. 1997. Bycatch management and the economics of discarding. FAO Fisheries Technical Paper No. 370. FAO, Rome, Italy.

Pope J.G. 1991. The ICES Multispecies Assessment Working Group: evolution, insights and future problems. ICES Mar. Sci. Symp. 193: 22-33.

Rochet M.J., Trenkel V.M. 2005. Factors for the variability of discards: assumptions and field evidence. Can. J. Fish. Aquat. Sci. 62: $224-235$. https://doi.org/10.1139/f04-185

Sandberg P. 2006. Variable unit costs in an output-regulated industry: the fishery. Appl. Econ. 38: 1007-1018. https://doi.org/10.1080/00036840500405912

Schopka S.A. 2007. Area closures in Icelandic waters and the realtime closure system: A historical review. Report series nr.133. The Marine Research Institution, Reykjavik, Iceland (in Icelandic with English summary).

Statistics Iceland. 2016. Retrieved from: http://www.statice.is/statistics/business-sectors/fisheries/

Stow C.A., Jolliff J., McGillicuddy D.J., et al. 2009. Skill assessment for coupled biological/physical models of marine systems. J. Mar. Syst. 76: 4-15 https://doi.org/10.1016/j.jmarsys.2008.03.011

Valdemarsen J.W. 2003. Report from a workshop on discarding in Nordic fisheries. Nordic Council of Ministers, Copenhagen, Denmark.

Woods P.J., Bouchard C., Holland D.S., et al. 2015. Catch-quota balancing mechanisms in the Icelandic multi-species demersal fishery: are all species equal? Mar. Policy 55: 1-10. https://doi.org/10.1016/j.marpol.2015.01.004 